\title{
Abbreviations of Works Cited
}

CP W. H. Auden, Collected Poems, ed. Edward Mendelson. New York: Random House, 1976.

DH W. H. Auden, The Dyer's Hand. London: Faber and Faber, 1963.

EA W. H. Auden, The Englisb Auden, ed. Edward Mendelson. New York: Random House, 1977.

EF W. H. Auden, The Enchafed Flood. Charlottesville: University Press of Virginia, 1979.

SP W. H. Auden, Selected Poems, ed. Edward Mendelson. New York: Random House, 1979. 

R E A D I NG A U D E N 
